\title{
Professional Learning Opportunities Regarding the Concept of Function in a Practice-based Teacher Education Program
}

\author{
André Luis Trevisan ${ }^{1 *}$, Alessandro Jacques Ribeiro ${ }^{2}$, João Pedro da Ponte ${ }^{3}$ \\ ${ }^{1}$ Universidade Tecnológica Federal do Paraná, Londrina/PR, BRAZIL \\ ${ }^{2}$ Universidade Federal do $A B C$, Santo André/SP, BRAZIL \\ ${ }^{3}$ Instituto de Educação, Universidade de Lisboa, PORTUGAL \\ *CORRESPONDENCE: $\triangle$ andreluistrevisan@gmail.com
}

\begin{abstract}
Teachers' professional knowledge has been an active area in the field of mathematics education research in the last decades, but we still know very little regarding how teachers learn. This article aims to identify learning opportunities experienced by two teachers regarding mathematical and didactical knowledge for the teaching of function, in a context of practice-based learning. To this end, we analyze data from a practice-based teacher education program based on a cycle that incorporates three segments of teachers' practice: planning, enacting and reflecting on a high school mathematics lesson, conducted from the perspective of inquiry-based teaching. We analyze two strands of the professional knowledge mobilized by the teachers, namely (i) the mathematics knowledge for teaching function, (ii) the knowledge for teaching practice, regarding function. The results indicate learning opportunities that emerged from the work done, regarding the use of the classroom as a teaching professional learning environment: the search for ways to encourage students to participate in the discussions; the recognition of the potential of the chosen lesson plan for the covariational approach, the importance of organizing mathematical discussion practices for students' learning, organizing the time devoted to whole-class discussions and preparing for leading them and the potential of a class developed from the perspective of inquiry-based teaching.
\end{abstract}

Keywords: mathematics education, mathematical knowledge, didactical knowledge, professional learning opportunities, professional learning tasks

\section{INTRODUCTION}

While recognizing the crucial role of teachers in student learning, approaches to their own initial and continuing education often do not help teachers to develop the necessary knowledge for practice (Ball \& Even, 2009). Highlighting the central importance that teacher professional knowledge has taken in research in mathematics education in recent decades, Charalambous and Pitta-Pantazi (2016) point out that there is a complex association between this knowledge, teaching practices and students' learning, and that this relationship is an open research theme. Likewise, Ponte and Chapman (2016) discuss the complexity of mathematics teacher education, indicating the development of knowledge of mathematics and of mathematics teaching as central elements of this process, which, albeit distinct, are inherently connected.

Also, more research is necessary to understand the relationship between the mobilization of teachers' professional knowledge and teachers' learning, as well as the contexts that support its development. Since teachers' professional knowledge is "above all oriented towards a practical activity (...), although relying on

Article History: Received 28 September $2019 \bullet$ Revised 23 October $2019 \bullet$ Accepted 23 October 2019

(C) 2020 by the authors; licensee Modestum Ltd., UK. Open Access terms of the Creative Commons Attribution 4.0 International License (http://creativecommons.org/licenses/by/4.0/) apply. The license permits unrestricted use, distribution, and reproduction in any medium, on the condition that users give exact credit to the original author(s) and the source, provide a link to the Creative Commons license, and indicate if they made any changes. 
knowledge of theoretical nature (...) and also of social and experiential nature" (Ponte, 2012, 3), approaches that promote professional learning opportunities (PLO) (Ribeiro \& Ponte, 2019) should consider and articulate different dimensions of this knowledge and the contexts in which it is mobilized (Silver, Clark, Ghousseini, Charalambous, \& Sealy, 2007). Assuming that "teachers' learning" includes changes in knowledge, beliefs and/or practices, and develops in activities such as planning and reflection (Goldsmith, Doerr, \& Lewis, 2014), we consider that a promising element in this process are professional learning tasks (PLT) (Ball \& Cohen, 1999), constructed from artifacts of practice, such as student work records, classroom documentation (images, audios), curriculum materials and teachers' notes.

Therefore, the goal of this paper is to survey and identify PLO experienced by two teachers, in a practicebased learning context, regarding the mathematical and didactical knowledge for teaching of function. In order to operationalize this goal, we formulate the following research questions: (i) what mathematical and didactical knowledge two teachers mobilize when planning, developing and collectively discussing a lesson about the concept of function? (ii) How working with PLT may serve as a basis for PLO in terms of mathematical and didactical knowledge for teaching function? To answer these questions, we initially present a theoretical framework that discusses the teachers' professional knowledge and the PLO, focusing on mathematical and didactical knowledge for teaching function. Then, we describe the practice-based teacher education program and the methodological procedures of the research. After analyzing and interpreting the data, we present the conclusions and final considerations.

\section{THEORETICAL FRAMEWORK}

\section{The Teachers' Professional Knowledge and the PLO}

Since Shulman (1986) introduced the idea of pedagogical content knowledge (PCK) as a specific kind of teacher knowledge that lies at the intersection of content and pedagogy, many authors have expanded and deepened this idea. For example, Ball, Thames and Phelps (2008) consider different subdimensions of Shulman's (1986) framework, highlighting teachers' specialized content knowledge, as kind of knowledge of content specific of teachers, and knowledge of content and students, allowing teachers to "anticipate what students are likely to think and what they will find confusing" (p. 401). Another author, Ponte (2012) argues that teachers' knowledge is action-oriented. For this author, this knowledge is "oriented to a practical activity (teaching mathematics to groups of students), although it relies on knowledge of a theoretical nature (on mathematics, education in general, and the teaching of mathematics) and of a social and experiential nature (about the students, the dynamics of the class, the values and culture of the surrounding community, the school and professional community, etc.)" (p. 3). From this perspective, the author emphasizes the knowledge of instructional processes, with emphasis in the selection of tasks and leading classroom communication (Ponte, 2012).

Our understanding of professional learning is aligned with the ideas of Goldsmith, Doerr and Lewis (2014), who assume that this "includes changes in knowledge, changes in practice, and changes in dispositions or beliefs that could plausibly influence practice" (p. 7). For these authors, such changes can be inferred, among other ways, either from cross-sectional data about teachers or from changes in their teaching practice. Considering that the professional knowledge is immersed, contextual and embodied in practice, WebsterWright (2009) argues that professional learning occurs from practical experience and reflection on this practice, from situated, social and constructed contexts that may represent dilemmas. The author highlights the need to think about educational proposals that take into account authentic experiences and that are in line with the reality of the workplace and professional responsibilities.

Ribeiro and Ponte (2019) characterize professional learning opportunities (PLO) as collective moments in which teachers work and discuss mathematical and didactical situations in order to mobilize different dimensions of their professional knowledge. In their view, tasks that can be used as a basis for PLO should promote experiences and discussions that stimulate teachers to reflect about their knowledge and encourage them to share their classroom practice experiences making their daily work the object of research and productive inquiry (Ball \& Cohen, 1999; Smith, 2001). As Smith (2001) points out, "teachers would develop an understanding of subject matter, of pedagogy, and of students as learners-critical components of a teacher's knowledge base for teaching (...) by investigating core tasks that are central to teaching" (p. 7).

Thus, approaches that provide opportunities for teachers' professional learning should focus on critical activities of the profession (on teaching and learning practices) (Ball \& Cohen, 1999), besides contemplating 
and articulating different dimensions of knowledge, associated with contexts in which knowledge is mobilized (Silver et al., 2007). The so-called professional learning tasks (PLT) (Ball \& Cohen, 1999) or practice-based professional learning tasks (Silver et al., 2007; Silver, 2009) should be focused on problems and cases of professional practice, structuring contexts that bring together artifacts from the teachers' daily work.

PLT share many of the characteristics of mathematical tasks for students, taken here as "organizing elements of the activity of those who learn" and may have or not "potential in terms of mathematical concepts and processes that can help mobilization" (Ponte, 2014, p. 16). However, PLT must serve other purposes. They are often constructed from artifacts of practice such as curriculum materials, videos or narratives of classroom episodes, samples of students' written productions, seeking to "create opportunities for teachers to ponder pedagogical problems and their potential solutions through processes of reflection, knowledge sharing, and knowledge building" (Silver et al., 2007, p. 263). They enable teachers to develop and (re)signify knowledge necessary for teaching practice and aim to "allow teachers to propose, debate, and consider solutions to pedagogical dilemmas and explore pedagogical possibilities as they move back and forth between past and current teaching experiences and the activity space of the professional development experience" (Silver, 2009, p. 245).

Working with PLTs can be developed analogously as a mathematics class from the perspective of inquirybased teaching (in which students work with tasks and develops in three moments: launching, students' autonomous work and whole-class discussions). For Ponte (2005), "the moments of reflection, discussion and critical analysis after the realization of a practical activity assume a fundamental role", because "learning stems, above all, notfrom listening directly to the teacher or doing this or that practical activity, but rather from the student's reflection on the activity he/she has done" (p. 15).

To support the teacher in promoting ("orchestrating”) these discussions, Stein, Engle, Smith and Hughes (2008) suggest a five-practice pedagogical model (anticipating, monitoring, selecting, sequencing, and making connections between students' responses) that can be adapted to the context of working with the PLT. In that model, the planning of the teachers' activity (in this case, the teacher educator), by anticipating the student's activity (in this case, the pre-service and in-service teachers), plays a fundamental role for promoting mathematical discussions, since the teacher educator decides what he/she will teach, how he/she will teach, how he/she will organize the classroom, the routines to be followed and how he/she will adapt the teaching (Serrazina, 2017).

\section{Mathematical and Didactical Knowledge for Teaching Function}

In order to investigate PLO concentrating on both mathematical and didactical knowledge when it has been working with the PLT in a context of practice-based professional learning, we chose the mathematical concept of function as a research focus. It is a central theme in the historical development of mathematics, present in both the mathematics curricula of basic education and in the disciplines of differential and integral calculus at the university.

Recalling historical elements from the development of this concept, Thompson (1994) points out that the "static image of function", as we know it, conceals many of the intellectual achievements that have brought us to our current conceptions. Since the 1930s, the notion of function as correspondence between elements of two sets has been taken as 'official', because it solved many problems historically introduced by people such as Fourier, who wanted to define functions by a boundary process. According to Thompson (1994), this definition has received strong pedagogical criticism, because, on the one hand, while significant for mathematicians, it is not for a student who is 'introduced' to the idea of function; on the other hand, it is a restrictive definition, which does not encompass many phenomena involving the joint variation of two quantities, but cannot be expressed by the correspondence between elements of two sets so that each element in the first corresponds exactly to an element in the second.

According to Thompson (1994), there is a tension between the thought of function as correspondence and function as covariation (the latter involving the coordinated analysis of variations of two interdependent quantities). For Thompson and Carlson (2017), "ideas of variation and covariation in variables' values no longer fit within today's mathematical definition of function” (p. 422), as they adopt the steps of determining points, Cartesian products, and Dirichlet's meaning of the need for the law of correspondence between variable values (in the case of functions between numeric sets). For the authors, "ideas of continuous variation and continuous covariation are epistemologically necessary for students and teachers to develop useful and robust 
conceptions of functions" (p. 422), allowing them to reflect on the "how" the quantities involved in a given situation are related.

According to Caraça (1951), a quantity is called "that which is the object of measurement", or at least that which, by nature, admits to being measured, even though we cannot effectively represent it by a number. For Thompson (1990), a quantity is a measurable quality of something, and its magnitude is the measure of a quantity in some unit. Thus, for the author, to reason quantitatively is to argue about quantities, their magnitudes, and their relationship with other quantities.

For Smith (2008), the genesis of functional thinking implies paying attention to the varying quantities and starting to focus on the relationship between these quantities. For Mestre (2014), young children face a variety of causal and dependence events in their daily lives, enabling this type of thinking to develop long before the concept of function is introduced in school. Thus, although the correspondence approach is traditionally more present in teaching and learning processes, a perspective of covariation in the construction of quantitative relationships may support a more flexible conception of function (Smith \& Confrey, 1994), based on ideas such as variation, approximation and proportion, fundamental in mathematics teaching and learning processes.

Pazuch and Ribeiro (2017), in a literature review on the professional knowledge of mathematics teachers and the concept of function, emphasize the need to work at in-service and pre-service teacher education, with the different meanings attributed to this concept. Regarding the relevant mathematical and didactical knowledge, one of the results pointed by the authors, from the analysis of Bisognin, Bisognin and Cury's papper (2010), is the predominance of the algebraic representation, together with the difficulty that teachers have in articulating it with other representations (natural language, tables and graphs). Even (1990) highlights that teachers need to understand the concept of function in its different representations, and to be able to translate and interconnect them, allowing a better, deeper, more powerful and more complete understanding, besides being familiar with the main useful approaches to the concept of function, knowing how to make good choices among those available. Another result pointed out by Pazuch and Ribeiro (2017), based on research by Zuffi and Pacca (2002), is that, in the teachers' conception, functions are materialized based on graphic representations, whereas the idea of abstract relationships between quantities ends up lost. Thus, it is necessary that the educational processes enable teachers to elaborate a deep knowledge of the concept of function, involving its different meanings.

\section{THE PRACTICE-BASED TEACHER EDUCATION PROGRAM}

The PLT work cycle adopted in our research is inspired by lesson study (Murata, 2011; Ponte, Quaresma, Mata-Pereira, \& Baptista) and incorporates three segments of teacher practice activities, here called the $P D R$ cycle (Planning, Development and Reflection): (i) in planning, in small groups, the teachers organize a lesson proposal on a specific mathematical concept, followed by a whole-group presentation and discussion and then, they chose a plan to be taught; (ii) in developing, one (or more) teacher(s) enact(s) the lesson plan in a classroom, and other teachers observe and take notes; and, finally, (iii) reflecting occurs after teacher the educator prepares episodes from the records of practice generated in the class (or classes) enacted, when teachers carry out detailed analysis of lesson episodes and discuss them in whole-group final session.

Considering that the working with the PDR cycle offers PLO, we used it as part of a teachers' education process involving "students" from a professional master's program in Teaching of Mathematics at a Brazilian University. This process was attended by 12 teachers and was held in 15 sessions of 3 hours each, during the 1st semester of 2018, with the first author assuming the role of teacher educator. The work dynamics was organized similarly to that described by Ponte, Mata-Pereira, Quaresma and Velez (2017), in a practice-based teacher education program conducted from an inquiry-based teaching perspective. Thus, each class alternated "moments of presentation of ideas and relevant information by the team of teacher educators, with practical work by the teachers following these presentations (in pairs or groups of three) and, finally, moments of wholegroup discussion" (Ponte et al., 2017, p. 80). In moments of whole-group discussion, the teachers were invited to present their solutions, discussing and agreeing or disagreeing on them. The role of the teacher educator was to "seek to value the work of teachers while, at the same time, framing it in curriculum perspectives and relating it to results of research on student learning" (Ponte et al., 2017, p. 80).

For this paper, we focus on data collection in sessions 10 through 14 of the program, where the three segments of the PDR cycle were developed. In sessions 10 and 11, planning (segment P of the PDR cycle), included the presentation and discussion of three lesson plans, targeting high school students (aged 16 and 17 


\section{Roadmap for Lesson Planning \\ (Adapted from Serrazina (2017, p. 24))}

Step 1 - Choose a good task and, at the same time, trace the learning you want to promote with the students.

Step 2 - From the task chosen and considering the learning you want to promote, set the goals you want to achieve with the class you have planned.

Step 3 - Seek to anticipate students' difficulties and their possible solution strategies for the task.

Step 4 - Anticipate possible teachers' questions and students' answers.

Step 5 - Define which materials and didactic resources will be needed for the class; use questioning to support student learning; have students work in groups.

Step 6 - Prepare, in addition to the anticipation already made in steps 3 and 4 , the other practices proposed by Stein and collaborators (2008), guidelines for the teacher who will teach the class to conduct classroom discussions (strategies for monitoring, selection, sequencing and connections between students' responses).

Step 7 - Prepare the students' task.

Figure 1. Lesson Planning Roadmap

\section{Roadmap for class observation \\ (Adapted from O'Donnell and Taylor (2007))}

1st) Regarding the management of class time:

a) Did the class enacted allow the participation and manifestation of the students or gave priority to the teacher's talk?

b) Did the class enacted allow students to understand and get involved throughout the activity?

c) Did the class enacted allow discussions in small groups and in whole-class?

2nd) Regarding the teacher's actions:

a) Did the teacher explain the necessary guidelines for the students to get involved in the class?

b) Did the teacher use questions and statements to help the students to understand the concepts?

c) Did the teacher use appropriate terminology (according to mathematics and to the students' age)

and appropriate language to help students make the necessary connections?

d) Did the teacher, at the end of the whole-class session, enable the systematization of the mathematical knowledge involved in the task?

3rd) Regarding the students' discussions in whole-class:

a) Did the teacher enable students to present different ways of accomplishing the task (including possible incorrect strategies)?

b) Did the teacher consider the difficulties presented by the students and make interventions to overcome them?

c) Did the teacher promote debate between the different strategies presented by the students and in relation to their difficulties?

Figure 2. Roadmap for class observation

years). The groups were provided with a roadmap (Figure 1) based on Serrazina (2017), with an organization to be taken as the basis for planning the class.

Thus, groups with four members organized the planning of a class to be enacted in 100 minutes, taking as a principle Stein et al.'s (2008) proposal, i.e., assuming that the chosen task can be the basis of a mathematical discussion. For their development, students should be organized in small groups, and it is essential that there must be time for whole-class discussion with them.

After this step, two teachers developed two of the lesson plans, elaborated and chosen from the previous phase, in their own high school classrooms (segment D). The discussions held by those groups of students during the class were recorded in audio, and their protocols in the work on the task proposed were collected at the end. Every class was recorded on video. In addition, the teacher educator and three other teachers, who participated in the planning and discussion of plans observed the class. In possession of an observation roadmap (Figure 2) adapted from O'Donnell and Taylor (2007), the teachers elaborated reports of their 
observation focusing on the teacher's role and actions and on the students' participation and involvement throughout the lesson. At the end of the class, all teachers made a report (videotaped) mediated by the teacher educator, in which they recorded their own perceptions about this process.

In possession of the material collected during the development of the class, the teacher educator and another researcher (second author) made clippings and selected episodes that were relevant to explore different dimensions of the teacher's professional knowledge, as well as the orchestration of the whole-class discussions promoted by the teachers. This process genereted episodes or vignettes (a set of features that characterize a particular episode, as proposed by Borko, Jacobs, Eiteljorg and Pittman, 2008). Sessions 12 to 14 (segment R) were devoted to the analysis of vignettes. For this stage, the researchers organized questions based on two dimensions: the students' role in solving the proposed task (the different solution strategies used), and the teachers' role and actions at three moments of lesson development (when presenting the task, monitoring of the group work and conducting the whole-class discussions). Initially, the teachers worked in small groups to analyze these vignettes and, at the end of each session, a whole-class discussion was organized by the teacher educator to share the reflections on this process.

\section{METHODOLOGY}

\section{Participating Teachers and Tasks Enacted in the Classroom}

Taking the nature of the goal of this study, a qualitative research approach was adopted (Bogdan \& Biklen, 1994; Esteban, 2010) under a theoretical interpretative focus (Crotty, 1998). Among the participants in the teacher education program, we selected two teachers who were involved in the collective development of lesson plans. The criteria used for choosing the two teachers were: (i) they were willing to participate in this research; (ii) they were teaching in high school; (iii) they were able to enact the lesson plan in their own classes; and (iv) they had compatible time schedules, so that other teachers participating in the program could accompany them. Each teacher was able to choose to carry out the lesson plan with which he/she most identified and which he/she deemed most appropriate for his/her class. In all, three plans were elaborated, and two of them were chosen by the teachers to be applied in their class. Both had been teaching for at least 8 years, and reported, throughout the teacher education program, to being used to develop their classes in a traditional perspective.

A teacher, Simone, has an undergraduate course on mathematics teaching and a specialization in education, and has experience as a mathematics teacher for middle and secondary school, since 2009. The lesson took place in high-school class, where Simone works as a temporary contracted teacher at a state public school in a small town in the state of Paraná/Brazil. That day, 18 students were present in class. They were organized into 6 groups defined by the teacher. Her lesson plan (Plan A) was organized from a task (Figure 3) presenting the first five terms of a sequence of figures constructed with matchsticks with a linear growth pattern. Initially, the students were required to determine the number of matchsticks of some subsequent positions. Afterwards, a scheme was presented, urging the students to observe the relationship between the variation of the positions and the number of matchsticks, in order to determine the number of matchsticks in a certain position, as well as to figure out the position, given the number of matchsticks. Finally, linear and exponential graphs were given, asking to determine which better represented the relationship between the position of the figure and the number of matchsticks.

The other teacher, Cássia, has a undergratute degree in science teaching, with qualification in mathematics, biology and chemistry, and a specialization in mathematics education, having taught in elementary and middle school grades (since 1986) and in secondary school (since 1990), as well as coordinating and directing schools. She carried out her class with her mathematics students in a private school, in a medium-sized municipality in the state of Paraná/Brazil. That day, 30 students attended the class, and organized themselves freely in groups of three. In her lesson plan (Plan B), a situation involving a change in the dimensions of a laundry detergent package was proposed, and the old and new dimensions were provided (Figure 4). The calculation of the total area and volume in each case was asked, questioning whether the change had brought any advantage for the company and/or for the consumer. Next (similar to the previous plan), two graphs are presented and the question is which represents better the relationship between the number of boxes produced by the company and the savings generated by the change in the model of the boxes. Finally, the students were requested to investigate the possibility of producing boxes with other dimensions, keeping the same volume, with a smaller amount of paper. 
Look the sequence of figures constructed using matchsticks arranged as follows:

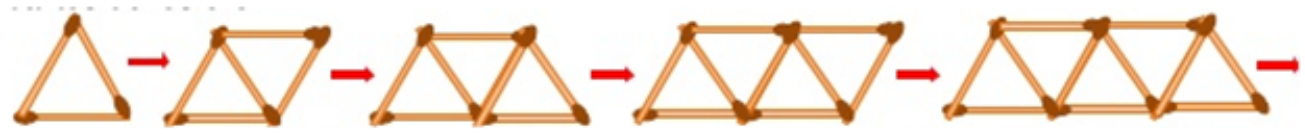

Answer the following questions, recording your thoughts through symbols, calculations, schemes, or words:

a) Represent the 6 th and 7 th figures of this sequence

b) How many matchsticks in total has the 12 th figure?

c) Build a table that lists the number of matchsticks in each figure, from the 1st to the 7th figures.

d) Observe the following scheme and complete the incomplete sentences.

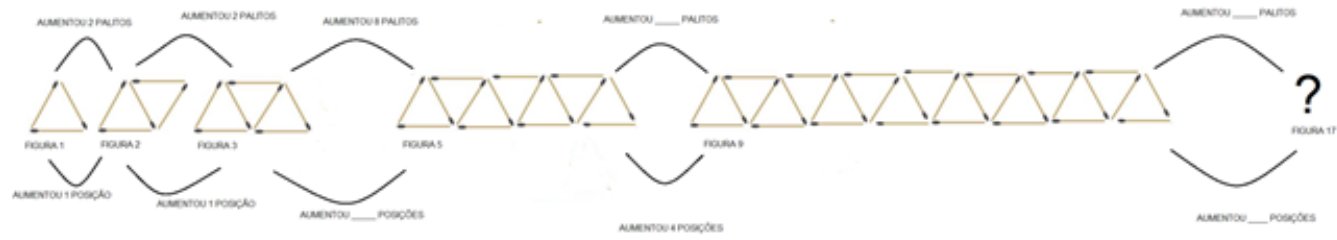

e) Describe how the previous scheme was completed.

f) How many matchsticks is there in the 29 th figure?

g) A picture has 101 matchsticks. What is its position in the sequence?

h) Which of the following graphs best represents the relationship between the position of the figure and the number of matchsticks? Explain your answer.

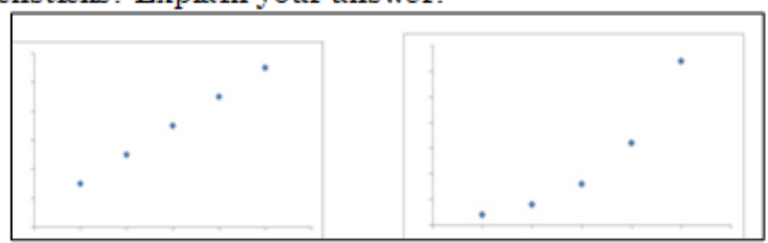

Figure 3. Lesson Plan A

Two boxes are used to pack laundry detergent. Box 01 was the model used for a long time and its dimensions are $4.8 \mathrm{~cm} \times 16.8 \mathrm{~cm}$ base and $24 \mathrm{~cm}$ high. Box 02 is the current model with the following dimensions: $19 \mathrm{~cm} \times 7 \mathrm{~cm}$ base and $14.5 \mathrm{~cm}$ high. [images omitted]

a) From the boxes exposed, calculate the total area of each box.

b) Now calculate the volume of the boxes.

c) Based on these calculations, were there any advantages for the company? What?

d) And for the consumer? What?

e) Which of the following graphs best represent the relationship between the number of boxes produced by the company and the savings generated by changing the model of the boxes? Explain your answer.

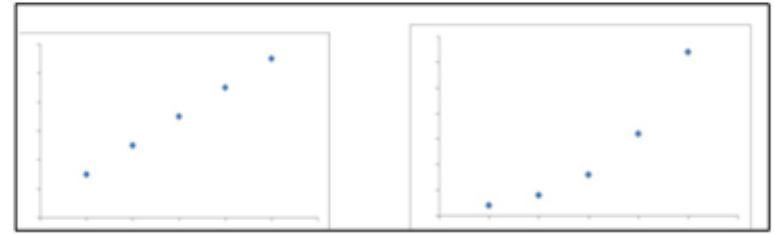

Figure 4. Lesson Plan B

\section{Data Collection and Organization}

Data for this paper were collected at different times of the enactment of the PDR cycle through: (i) audio and written protocols of groups of teachers in the practice-based teacher education program planning step 
(Plan); (ii) video records of the classroom with two cameras, one of which directed to the teacher and the other to the students (Dev); (iii) written reports prepared by the teachers in the practice-based teacher education program, who followed the class as observers (RepOb), based on a roadmap; (iv) video records of the teachers' reports at the end of the class, recording their perceptions about this process (RepTeacher); and (v) research journal of the teacher educator.

For the analysis, we tried to identify, in the collected data set, elements that could raise and identify PLO experienced by teachers with regard to mathematical and didactical knowledge for teaching function at basic education. Therefore, the categories considered were the two strands of the mathematics teachers' professional knowledge mobilized by the teachers involved in working with the PDR cycle: (i) mathematics knowledge for teaching function, and (ii) knowledge of teaching practice when teaching function.

In the following section, we present evidence and interpretations derived from the data collected at each of the development steps of the PDR cycle. We bring transcripts of teachers' dialogues and written records of the observers and teacher educator in italics to point out evidence that has subsidized our analysis. We indicate in parentheses the name of the teacher who produced such evidence, followed by the type of procedure/instrument that originated such data.

\section{RESULTS}

In this section we present and analyze the categories that emerged from the data regarding the TWO broad strands of the mathematics teachers' professional knowledge mobilized by the teachers involved in working with the PDR cycle: (i) mathematical knowledge for teaching function, and (ii) knowledge of teaching practice when teaching function.

\section{Mathematical Knowledge for Teaching Function}

In the Plan A proposal, the class should encompass aspects of the concept of function in a covariational perspective, since this was the central theme of the whole program. Conceptual aspects concerning the thinking of a function such as covariation had been discussed in several meetings prior to the PDR cycle. Although Simone did not participate in the elaboration of Plan A (which she enacted in her class), she acknowledged during the presentation of the lesson plans that it had potential for exploring covariational thinking. In particular, an item of the task that brought a scheme exploring the relationship between the variation of positions and the number of matchsticks in the sequence called her attention, and she recognized in it the possibility of promoting this kind of thinking, putting into evidence the mathematical knowledge for teaching function.

A reason for Simone's choice was that Plan A involves an "open" task that did not require students to have specific previous mathematical knowledge (such as formulas for calculating areas and volumes as in Plan B). It seeks to understand that the relationship between the position of the figure and the number of matchsticks involve quantitative reasoning, allowing the student to argue about quantities involved and the relationship between them.

In the lesson enactment, Simone sought to encourage the students to observe that the increase of a position in the sequence leads to the increase of two matchsticks, and to recognize the relationship must that be used to determine the number of matchsticks in a given position as $2 n+1$. Thus, she seeks to articulate the question of the correspondence between the position and number of sticks, with the variational aspect of the sequence. When asked, at the end of the class, what learning goal she expected students to achieve with the development of the plan, she says:

To realize that from one position to the other it increases by 2, and that the relationship between position and value is $2 n+1$ (Simone, RepTeacher).

In her discourse, Simone shows an understanding of the concept of function in its different representations, showing not only focus on the explicit use of formulas (although recognizing how important they are), but the coordinated analysis of variations of two interdependent quantities. She recognizes, in moments of reflection after class, some limitation in the way the discussions were conducted, justifying her action based on the students' "expectation" regarding the need to use formulas:

I didn't want them to get stuck in formulas, though students sometimes need them to validate what they do (Simone, RepTeacher). 
Simone reports that, during class, she sought to observe how each group solved the task. Although during the planning step the teachers anticipated possible solutions for the task, others emerged in the groups:

I would never think that way. (Simone, RepTeacher)

Simone reports to have chosen to start the whole-class discussion from one of those solutions that were different from the anticipated ones, because she recognized the potential of that strategy for a covariational approach. Based on the scheme in item (d) of the task, the group realized that, as there were 35 matchsticks in the 17 th position, the total of sticks in the 29 th position would be $35+2 \times 12=59$. The teacher brings this solution to the whole-class discussion, seeking to consider with the students covariational aspects of the situation, both in the relationship between the variation of the position of the figure and the number of matchsticks, and the determination of numbers of sticks in a specific position.

Cassia chose to develop Plan B in her class. The teacher recognizes that initially this plan did not show an explicit relationship with the covariational approach to the concept of function:

I was a little worried about that. Initially, when I got the plan, it did not have that feature [referring to the covariational approach]. As it was presented, it does not include covariational reasoning [...] But it has potential, if adjustments are made (Cassia, Plan).

Cassia suggested, when discussing the lesson plans (at the final phase of step R) the insertion of an item in the task: to choose, from two graphs, which would best represent the relationship between the number of boxes produced by the company and the economy generated by the change in the model of the boxes. Another criterion evidenced by Cassia in her choice was that the context of the task would be integrated to the theme addressed at that time in her geometry class. In addition to a matter of convenience, she recognizes that geometry encompasses phenomena involving the joint variation of two quantities:

The plan involves the subject that we are working on. I think geometry will combine better (Cassia, Plan).

Cassia recognized in item (e) of the task (Figure 3) the potential for a covariational approach, and sought, both in the interventions that she carried out with the student groups and during the whole-class discussion, to focus on this type of approach. However, even after the whole-class discussion, she noticed that two of the groups were still confused about this item, choosing to resume it in the next class:

There were two groups that insisted on graph 2. I cannot let this issue without explaining. And as it involves concepts such as graphics, function, I think it's worth resuming it [...] I could see a confusion about the arithmetic and geometric progression, so I think the question deserves to be taken up again (Cassia, RepTeacher).

When verifying difficulties, especially the one that arose about the analysis of the proposed graphs, the teacher questioned them, seeking to lead the students to correct wrong thinking, there was only a conclusion missing regarding the graphical analysis (About Cassias's class, RepOb2).

Cassia also highlights it is necessary to reformulate the statement of the question, which was not very clear for the students, and some adjustment in its formulation to show more significantly the covariational aspect of the situation:

I believe the way the situation was presented also did not allow the students to contemplate a wide variety of possibilities to solve the problem. In addition, covariational thinking has been left in the background at times (About Cassia's class, RepOb3).

I think this activity, as planned, did not allow the development of covariational thinking (RepOb4).

Asked by the teacher educator about which strategy to use in this new discussion about the choice of graphs, she reported that "she intends to simulate values and score points in the plan to make the graph", highlighting the variation between the number of boxes and the savings generated. This shows that she values the articulation between different representations as a necessary aspect for learning the concept of function, reinforcing the covariational aspect present in the situation.

\section{Knowledge of Teaching Practice when Teaching Function}

In the case of Simone's lesson, following Plan A, the students were very shy at the beginning of the class, an aspect highlighted by the teacher herself and also present in the observers' reports:

As for the whole-class discussion, the students were intimidated, I think by the presence of the cameras and researchers who were strangers to them (About Simone's class, RepOb2). 
This limitation, however, made the teacher (although also apprehensive) seek to follow the discussion in the groups, and look for ways to entice the students to participate in the discussion at the time of the wholeclass discussion. This aspect is present in the reports of the observers of the class:

The class allowed the effective participation of the students, enabling them to manifest themselves. There was interaction between the students and the teacher, and this encouraged them to reason and reach their conclusions regarding the proposed activity (About Simone's class, RepOb2).

At the beginning of the activity, the students showed difficulties, but throughout the development, all became involved [...] The teacher was present all the time, explaining and answering the questions asked by the students, showing interest in the students' learning process [...] In the course of the activity, she was promoting group discussions and the development of the activities. (About Simone's class, RepOb1).

The class allowed the effective participation of the students, enabling them to manifest themselves. There was interaction between the students and the teacher, and this encouraged them to reason and reach their conclusions regarding the proposed activity (About Simone's class, RepOb2).

When developing lessons, both teachers showed some difficulty in articulating the time devoted to the solution of the tasks and the time for the whole-class discussion, because it is not a usual practice for them. Even so, they were able to develop the lesson from the perspective of inquiry-based teaching, by introducing the task, making time available for autonomous work in the groups, and finally organizing a whole-class discussion. The recognition of the potential of a lesson held from thiz perspective of teaching was an important aspect of the professional learning of both teachers. Thus, Simone highlights:

I plan to do this in other classes. I chose to do my master's because I was dissatisfied with the traditional methodology (Simone, RepTeacher).

The teachers were able to select groups that used different solution strategies for the whole-class discussion, trying, in the end, to establish some connection between the mathematical ideas reflected in the strategies and representations they used. Cássia reported, after the class, that initially she invited to wholeclass discussion groups in which the members are "more argumentative" while working with the tasks:

In the whole-class discussion, the teacher asked the groups individually about how they reached their conclusion, only in the expository sense, to the others. When checking the students' difficulties, the teacher commented that the way they used could have been directed to another strand, and they lacked stimulating the whole-class debate about the differences in the development of the task to reach the solution (About Simone's class, RepOb2).

They also recognized the need to organize more systematically the time devoted to whole-class discussions, as well as the practice of anticipation as a key element for both group interventions and whole-class discussions:

Due to the discussions, the time of the whole-class work was eventually affected and the activity could not be fully contemplated (About Cassia's class, RepOb3).

I think it could have been better. It was an activity for which I did not schedule the time correctly, see (Cassia, RepTeacher).

I don't think I was so prepared to conduct it. I think I got a little lost. We get a little lost as to what to do, to lead the discussion (Simone, RepTeacher).

I know that I still need to improve a lot, deepen my mathematical knowledge and perfect new teaching practices, and this will only be possible with much study (Simone, Plen).

Although the teachers had a negative view of their own performance in conducting the class, in the view of the observers they promoted discussions that, although not systematized, enabled the students' involvement and participation:

During the activity the teacher mediated the thinking and the questioning, stimulating the students. In the whole-class discussion, after the groups made the presentation of their conclusions, the teacher was relating and systematizing the mathematical knowledge used (About Simone's class, RepOb2).

The dynamics proposed by this class provided the opportunity for students to participate and manifest themselves in the development of this activity, allowing discussions in groups and in whole-class discussion (About Cassia's class, RepOb4). 
Cassia says her choice for Plan B was because, besides involving subject with which she was already working in class, she thought it had more potential to engage students. For her, the task in lesson plan A was very similar to the tasks the students had worked on the previous year, and that could demotivate them:

They already knew mathematical sequences. My fear is that they go straight to formulas [without exploring the task]. I think it has to be something that catches their attention, be new, for them to participate. (Cássia, Plan)

Despite the predisposition of both teachers to develop a class with the presence of observers, both reported, after the class, that they were quite apprehensive with the presence of the teacher educator, of the other teachers, cameras and recorders. However, they recognized the experience as positive:

I've never felt so cornered like that. This is an uncomfortable situation. The students were a little nervous, apprehensive. It is a difficult time. Now I wonder: it could be different, more natural. (Cassia, RepTeacher)

I was very nervous, I didn't know what to do or how to do it (Simone, RepTeacher).

\section{DISCUSSION}

The data analysis suggests that the actions of planning, developing and reflecting collectively a lesson offered a PLO to the teachers involved (Ribeiro \& Ponte, 2019). By incorporating these three segments of teaching practice, the PDR cycle has turned the teacher's daily work into an object of investigation (Smith, 2001). A central aspect of this process was the fact that the cycle is immersed and incorporated into the teacher's practice (Ball \& Even, 2009; Webster-Wright, 2009).

As for the PLO concerning mathematics knowledge for teaching function, we highlight the identification of potential (or not) of the lesson plans regarding the mobilization of the concept of function in a covariational perspective. Such identification is shown as a result of ideas discussed throughout the program and that somehow influenced teachers' choices of lesson plans.

According to Webster-Wright (2009), the investigation of these lived experiences of continuing to learn as professionals is fundamental to advance the understanding of promising practices for authentic professional learning. We recognize that the PDR cycle has offered teachers a PLO for them to develop and (re)signify mathematical knowledge concerning the concept of function from the covariational perspective, that is necessary for pedagogical practice (Silver et al., 2007). This fact is shown by their actions during the class by exploring aspects related to "how" the quantities involved in the situation were related (Thompson \& Carlson, 2017), without prioritizing (but also taking into account) a purely algebraic approach. One of the aspects that we highlight in Simone's practice is how she articulated, in her interventions in the groups, the question of the correspondence between the position and number of matchsticks and the variational aspect of the sequence. In articulating them, the teacher takes distance from the approach traditionally present in teaching and learning processes that favor only one type of approach (Smith \& Confrey, 1994).

With regard to the PLO on teaching-related learning when teaching function, we highlight, in the planning phase of the PDR cycle, that the teachers can choose a lesson plan with which they identified and felt safe, and the willingness to enact the class even in the presence of observers, while atuned with the reality of their workplace and professional responsibilities (Webster-Wright, 2009). Such aspects corroborated the perspective that teachers can be encouraged to continue to learn in an authentic way by considering proposals articulated with expectations that emerge from their work contexts. This situated and social nature of learning that takes into account the reality of the workplace (Goldsmith, Doerr, \& Lewis, 2014) has a positive impact on the PLO.

In the development of the lesson, despite being apprehensive, the teachers sought to involve the students in the development of the task, encouraging them to express themselves and participate in the discussions. Although at various times the way students handled the assignment proved to be different from what had been anticipated, teachers tried to listen to them as they passed through the groups to promote interventions that would provide opportunities for students to learn. The challenges faced in putting into practice a class model that intends to "give voice" to students and promote mathematical discussions different from the expository practice to which teachers were used, proved to be PLO. This productive imbalance (Ball \& Cohen, 1999) stimulated reconsideration about the way they acted.

The difficulty in articulating the issue of time management led the teachers to make explicit, in a moment of reflection, their recognition of the importance of the practice of anticipation (Stein et al., 2008) for the orchestration of mathematical discussions. Through their actions and reflections, we infer a 
reconceptualization about the processes of mathematical learning, with a shift of emphasis from passive development to active learning. The recognition of the importance of planning, coupled with the appropriate choice of tasks and the anticipation of student solutions as a means to better manage the class (Serrazina, 2017), evidences PLO arising from the experience with the PDR cycle.

We also highlight as PLO the recognition of the importance of organizing anticipatory practices, monitoring, sequencing and establishing connections between student responses (Stein et al., 2008). Despite their limitations in the systematic application of such practices (because it was something new for them), the teachers knew how to use the work developed in the students' groups to conduct the whole-class discussion. We infer that the work with other PLT throughout the practice-based teacher education program, as well as interactions with the teacher educator and other participants, provided confidence to the teachers in conducting this work.

We recognize in the teachers' actions during their lessons, the mobilization of elements present in the work dynamics used by the teacher educator during the process, conducted from the perspective of inquiry-based teaching. Thus, when monitoring the work in the groups and when conducting the whole-class discussion, teachers sought to value the students' work (Ponte et al., 2017). In addition, the data show the appreciation by teachers, both in their actions during lessons and in moments of reflection after them, of practices of conducting whole-class discussions (Stein et al., 2008) for the students' understanding and learning (Ponte, 2005, 2017). This corroborates that work with the PDR cycle offered PLO to learn new approaches to teaching and learning mathematics (Ribeiro \& Ponte, 2019) and to build new perspectives on their performance as teachers (Ball \& Cohen, 1999).

\section{CONCLUSION}

This practice-based teacher education program was conducted from the perspective of inquiry-based teaching, in which the participants were constantly involved in moments of whole-group discussion. Engaging in a cycle of classroom planning, development, and reflection in which they were invited to "transpose" this dynamic into their own classrooms enabled teachers to engage in authentic learning experiences (WebsterWright, 2009).

The PDR cycle, as a suggestion of work with professional learning tasks (Ball \& Cohen, 1999) that incorporate these three segments of teachers' professional activities, proved to be a promising proposal in terms of PLOs immersed in professional practice. In terms of the PLO emerging from the development and reflection of the collectively planned lessons, we identified: the search for ways to encourage students to participate in the discussions; the recognition of the potential of the chosen lesson plan for the covariational approach; the recognition of the importance of organizing mathematical discussion practices for students' learning; the recognition of the importance of organizing the time devoted to whole-class discussions and preparing for leading them; the recognition of the potential of a class developed from the perspective of inquirybased teaching.

In line with Webster-Wright's (2009) recommendations, this paper examines, based on empirical data, how teachers learn in and from their own experience. In this study, we illustrate some possibilities for teachers to be aware of how much can be learned by taking the mathematics classroom as a professional learning space, based on the approach taken in the practice-based teacher education program, organized from tasks that offer PLOs embedded and built during and from practice.

\section{Disclosure statement}

No potential conflict of interest was reported by the authors.

\section{Notes on contributors}

André Luis Trevisan - Universidade Tecnológica Federal do Paraná, Londrina/PR, Brazil.

Alessandro Jacques Ribeiro - Universidade Federal do ABC, Santo André/SP, Brazil.

João Pedro da Ponte - Instituto de Educação, Universidade de Lisboa, Portugal. 


\section{REFERENCES}

Ball, D. L., \& Cohen, D. K. (1999). Developing practice, developing practitioners: Toward a practice-based theory of professional education. In G. Sykes \& L. Darling-Hammond (Eds.). Teaching as the learning profession: Handbook of policy and practice (pp. 3-32). San Francisco, CA: Jossey Bass.

Ball, D. L., \& Even, R. (2009). Strengthening practice in and research on the professional education and development of teachers of mathematics: Next steps. In R. Even \& D. L. Ball (Eds.). The professional education and development of teachers of mathematics: The 15th ICMI study (pp. 255-257). New York, NY: Springer. https://doi.org/10.1007/978-0-387-09601-8_27

Bisognin, E., Bisognin, V., \& Cury, H. N. (2010). Conhecimentos de professores da educação básica sobre o conceito de função. In Anais do X Encontro Nacional de Educação Matemática. Brasília, SBEM.

Bogdan, R., \& Biklen, S. (1994). Investigação qualitativa em educação. Porto: Porto Editora.

Borko, H., Jacobs, J., Eiteljorg, E., \& Pittman, M.E. (2008). Video as a Tool for Fostering Productive Discussions in Mathematics Professional Development. Teaching and Teacher Education, 24, 417-436. https://doi.org/10.1016/j.tate.2006.11.012

Charalambous, Y. C., \& Pitta-Pantazi, D. (2016). Perspectives on Priority Mathematics Education: Unpacking and Understanding a Complex Relationship Linking Teacher Knowledge, Teaching, and Learning. In: L. D. English \& D. Kirshner (Eds.), Handbook of international research in mathematics education (3 ${ }^{\text {rd }}$ Ed., pp. 19-59), New York.

Crotty, M. (1998). The foundations of social research: meaning and perspective in the research process. London: Sage.

Esteban, M. P. S. (2010). Pesquisa qualitativa em educação: fundamentos e tradições. Porto Alegre: Artmed.

Even, R. (1990). Subject matter knowledge for teaching and the case of functions. Educational Studies in Mathematics, 21(6), 521-544. https://doi.org/10.1007/BF00315943

Goldsmith, L. T., Doerr, H. M., \& Lewis, C. C. (2014) Mathematics teachers' learning: a conceptual framework and synthesis of research. Journal of Mathematics Teacher Education, 17, 5-36. https://doi.org/10.1007/s10857-013-9245-4

Mestre, C. M. M. V. (2014). O desenvolvimento do pensamento algébrico de alunos do $4 .^{\circ}$ ano de escolaridade: uma experiência de ensino (Ph.D. Thesis in Education), Universidade de Lisboa. Lisboa.

Murata, A. (2011). Introduction: Conceptual overview of lesson study. In: L. Hart, A. Alston, \& A. Murata (Eds.), Lesson study research and practice in mathematics education (pp. 1-12). Dordrecht: Springer. https://doi.org/10.1007/978-90-481-9941-9_1

O’Donnell, B., \& Taylor, A. (2007). A lesson plan as professional development? You've got be kidding. Teaching Children Mathematics, 272-278.

Pazuch, V., \& Ribeiro, A. J. (2017). Conhecimento profissional de professores de matemática e o conceito de função: uma revisão de literatura. Educação Matemática Pesquisa, 19, 465-496. https://doi.org/10.23925/1983-3156.2017v19i1p465-496

Ponte, J. P. (2005). Gestão curricular em Matemática. In: GTI (Ed.). O professor e o desenvolvimento curricular (pp. 11-34). Lisboa: APM.

Ponte, J. P. (2012). Estudando o conhecimento e o desenvolvimento profissional do professor de matemática. In: N. Planas (Ed.), Educación matematics: Teoría, critica y prática. Barcelona: Graó.

Ponte, J. P. (2014). Tarefas no ensino e na aprendizagem da Matemática. In: J. P. da Ponte (Org.). Práticas profissionais dos professores de matemática (pp. 13-27). Lisboa: Instituto de Educação da Universidade de Lisboa.

Ponte, J. P. (2017). Discussões coletivas no ensino-aprendizagem em Matemática. In: GTI (Ed.). A prática dos professores: planificação e discussão coletiva na sala de aula (pp. 33-56). Lisboa: APM.

Ponte, J. P., \& Chapman, O. (2016). Prospective mathematics teachers' learning and knowledge for teaching. In L. English \& D. Kirshner (Eds.), Handbook of international research in mathematics education (pp. 275-296). New York, NY: Routledge/Taylor \& Francis

Ponte, J. P., Mata-Pereira, J., Quaresma, M., \& Velez, I. (2017). Formação de professores dos primeiros anos em articulação com o contexto de prática de ensino de matemática. Relime, 20(1), 71-94. https://doi.org/10.12802/relime.17.2013 
Ponte, J. P., Quaresma, M., Mata-Pereira, J., \& Baptista, M. (2016). O estudo de aula como processo de desenvolvimento profissional de professores de matemática. BOLEMA, 30(56), 868-891. https://doi.org/10.1590/1980-4415v30n56a01

Ribeiro, A. J., \& Ponte, J. P. (2019). Professional learning opportunities in a practice-based teacher education program about the concept of function. Acta Scientiae, 21, 49-74. https://doi.org/10.17648/acta.scientiae.v21iss2id5002

Serrazina, L. (2017). Planificação do ensino-aprendizagem da Matemática. In: GTI (Ed.), A prática dos professores: planificação e discussão coletiva na sala de aula (pp. 9-32). Lisboa: APM.

Shulman, L. (1986). Those who understand: Knowledge growth in teaching. Educational Researcher, 15(2), 414. https://doi.org/10.3102/0013189X015002004

Silver, E. A. (2009).Toward a More Complete Understanding of Practice-Based Professional Development for Mathematics Teachers. In: R. Even \& D. L. Ball (Eds.), The Professional Education and Development of Teachers of Mathematics: the 15th. ICMI study (pp. 245-247). Springer. https://doi.org/10.1007/9780-387-09601-8_25

Silver., E. A., Clark, L. M., Ghousseini, H. N., Charalambous, Y. C., \& Sealy, J. T. (2007) Where is the mathematics? Examining teachers' mathematical learning opportunities in practice-based professional learning tasks. Journal of Mathematics Teacher Education, 10(4-6), 261-277. https://doi.org/10.1007/s10857-007-9039-7

Smith, E. (2008). Representational thinking as a framework for introducing functions in the elementary curriculum. In: J. J. Kaput, D. W. Carraher, \& M. L. Blanton (Eds.), Algebra in the early years (pp. 133160). Reston, VA: NCTM. https://doi.org/10.4324/9781315097435-6

Smith, E., \& Confrey, J. (1994). Multiplicative structures and the development of logarithms: what was lost by the invention of function. In: G. Harel, \& J. Confrey (Eds.), The development of multiplicative reasoning in the learning of mathematics (pp. 333-360).

Smith, M. (2001). Practice-based professional development for teachers of mathematics. Reston: National Council of Teachers of Mathematics.

Stein, M. K., Engle, R. A., Smith, M. S., \& Hughes, E. K. (2008). Orchestrating Productive Mathematical Discussions: Five Practices for Helping Teachers Move beyond Show and Tell. Mathematical Thinking and Learning, 10(4), 313-340. https://doi.org/10.1080/10986060802229675

Thompson, P. W. (1990). A theoretical model of quantity-based reasoning in arithmetic and algebraic. Center for Research in Mathematics \& Science Education: San Diego State University.

Thompson, P. W. (1994). Students, functions, and the undergraduate mathematics curriculum. In: E. Dubinsky, A. H. Schoenfeld, \& J. J. Kaput (Eds.), Research in Collegiate Mathematics Education I (pp. 21-44). Providence: American Mathematical Society.

Thompson, P. W., \& Carlson, M. P. (2017). Variation, covariation, and functions: Foundational ways of thinking mathematically. In: J. Cai (Ed.), Compendium for research in mathematics education (pp. 421456). Reston, VA: National Council of Teachers of Mathematics.

Webster-Wright, A. (2009) Reframing Professional Development through Understanding Authentic Professional Learning. Review of Educational Research, 79, 702-739. https://doi.org/10.3102/0034654308330970

Zuffi, E. M., \& Pacca, J. L. A. (2012). O conceito de função e sua linguagem para os professores de matemática e de ciências. Ciência \& Educação, 8(1), 1-12. https://doi.org/10.1590/S1516-73132002000100001 